ARTICLE

\title{
Important causes of chronic kidney disease in South Africa
}

\author{
M R Moosa, ${ }^{1} \mathrm{MB} \mathrm{ChB}, \mathrm{FCP}(\mathrm{SA}), \mathrm{MD}, \mathrm{FRCP}$ (Lond); I van der Walt, ${ }^{2} \mathrm{MB} \mathrm{ChB}, \mathrm{MMed}$ (Int), Cert Nephrology (SA); \\ S Naicker, ${ }^{3} \mathrm{MB}$ ChB, MRCP, FRCP (Lond), FCP (SA), PhD; A M Meyers, ${ }^{4}$ MB BCh, FCP (SA), Cert Nephrology (SA), FRCP (Lond) \\ ${ }^{1}$ Division of Nephrology, Department of Medicine, Faculty of Medicine and Health Sciences, Stellenbosch University, Cape Town, South Africa \\ ${ }^{2}$ Netcare Jakaranda Hospital, Pretoria, South Africa \\ ${ }^{3}$ School of Clinical Medicine, Faculty of Health Sciences, University of the Witwatersrand, Johannesburg, South Africa \\ ${ }^{4}$ Donald Gordon Medical Centre, Klerksdorp Hospital, and National Kidney Foundation of South Africa, Johannesburg, South Africa
}

Corresponding author: A M Meyers (nkfsa@mweb.co.za)

In hypertensive patients without chronic kidney disease (CKD) the goal is to keep blood pressure (BP) at $\leq 140 / 90 \mathrm{mmHg}$. When CKD is present, especially where there is proteinuria of $\geq 0.5 \mathrm{~g} / \mathrm{day}$, the goal is a BP of $\leq 130 / 80 \mathrm{mmHg}$. Lifestyle measures are mandatory, especially limitation of salt intake, ingestion of adequate quantities of potassium, and weight control. Patients with stages $4-5$ CKD must be carefully monitored for hyperkalaemia and deteriorating kidney function if angiotensin-converting enzyme (ACE) inhibitors or angiotensin II receptor blockers (ARBs) are used, especially in patients $>60$ years of age with diabetes or atherosclerosis. BP should be regularly monitored and, where possible, home BP-measuring devices are recommended for optimal control.

Guidelines on the use of antidiabetic agents in CKD are presented, with the warning that metformin is contraindicated in patients with stages 4 - 5 CKD.

There is a wide clinical spectrum of renal disease in the course of HIV infection, including acute kidney injury, electrolyte and acid-base disturbances, HIV-associated glomerular disease, acute-on-chronic renal disease and side-effects related to the treatment of HIV.

S Afr Med J 2015;105(4):320. DOI:10.7196/SAMJ.9535

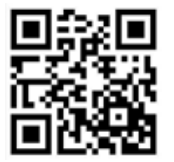

\section{Blood pressure and chronic} kidney disease

From 1999 to 2006 South Africa (SA) has seen a $67 \%$ rise in deaths owing to chronic kidney disease (CKD), and the prevention of this condition remains an important priority. Although accurate statistics are not available in SA, hypertension and type 2 diabetes mellitus (in line with worldwide trends) are the dominant diseases associated with end-stage kidney disease (ESKD), particularly in black ethnic groups. Levels of systolic and diastolic blood pressure (BP) are directly linked to the prevalence of $\mathrm{CKD}$ and the components of the metabolic syndrome.

Prevention of CKD at the population level requires interventions that improve lifestyles that lead to a reduction in BP, obesity, type 2 diabetes mellitus (DM) and smoking. At the primary practitioner level, it is mandatory to measure BP in all adult patients and, if the patient has hypertension, to routinely screen for evidence of CKD (urine dipsticks, and serum creatinine (with calculate glomerular filtration rate (GFR)) and associated comorbidities, such as type 2 DM.

\section{Treatment of hypertension without overt CKD}

- Patients with established hypertension should be treated in accordance with the South African Hypertension Society guidelines.

- The goal BP is $<140 / 90 \mathrm{mmHg} .{ }^{[1]}$

- It is particularly important to recognise patients at greatest risk for the development of malignant hypertension and progression to ESKD. These patients usually have severe hypertension (BP $>180 / 100 \mathrm{mmHg}$ ) and are often young, lean black males without other major risk factors. It is important to initiate combination therapy with at least two antihypertensive agents, and patients should be followed up within 7 days to assess BP response.
Treatment of hypertension in patients with established CKD

- Hypertension is a cause of CKD and aggravates existing CKD, resulting in a vicious cycle. Antihypertensive therapy has been proven to disrupt this cycle.

- Hypertension is also a potent risk factor for cardiovascular disease (CVD). Control of hypertension prevents cardiovascular morbidity and mortality, especially in CKD.

- It is important to understand that the pathogenesis of hypertension in CKD is related to overactivity of the renin-angiotensinaldosterone and sympathetic nervous systems, and volume overload. Angiotension II also plays an important role in the progression of CKD. These basic facts underlie the rationale for antihypertensive therapy.

- The most important objective of antihypertensive treatment is to achieve a BP of $<130 / 80 \mathrm{mmHg}$; the secondary objective being to reduce proteinuria to at least $0.5 \mathrm{~g} / 24$ hours or $<0.05 \mathrm{~g} / \mathrm{mmol}$ on spot urine.

- Lifestyle changes are an essential adjunct to antihypertensive drugs. Smoking cessation, exercise and weight loss are encouraged and sodium content of the diet reduced to $<100 \mathrm{mmol} /$ day. The latter can be checked by 24 -hour urinary sodium analysis. Nonsteroidal anti-inflammatory drugs (NSAIDs) and other drugs that raise $\mathrm{BP}$ or worsen renal function must be avoided.

- In the absence of contraindications (bilateral renal artery stenosis, planned pregnancy or history of angioedema (angiotensinconverting enzyme (ACE) inhibitor only)), ACE inhibitors or angiotensin II receptor blockers (ARBs) are the preferred first-line drugs of choice, especially if proteinuria is present. The agents should be titrated to their maximum recommended dosages.

- Treatment with ACE inhibitors and ARBs must be carefully monitored, especially in patients with stages 3 and 4 CKD who are prone to develop hyperkalaemia and deterioration in renal function, particularly if there is prerenal failure owing to overuse of diuretics 
or inter-current illnesses. However from a physiological perspective, reninangiotensin system (RAS) inhibitors cause a rise in creatinine owing to a reduction in intraglomerular pressure - a $20 \%$ or less rise in creatinine is acceptable. The RAS inhibitor may be continued provided there is no further deterioration in renal function and the serum $\mathrm{K}^{+}$remains $<5.6 \mathrm{mmol} / \mathrm{L}$. However, any greater rise should prompt the physician to withdraw the RAS inhibitor after excluding dietary contributions.

- In the majority of patients combination therapy is required, often with $\geq 3$ antihypertensive drugs to reach the target BP. The next antihypertensive added to the RAS inhibitor is either a calcium channel blocker or a diuretic or both. Both enhance the activity of RAS inhibitors, and calcium channel blockers avoid the metabolic sideeffects of diuretics. However, diuretics are preferred when volume overload is present.

- Thiazide or thiazide-like diuretics should be used in patients with normal renal function, and loop diuretics if renal function is impaired. Hydrochlorothiazide can be titrated to a dose of $25 \mathrm{mg} /$ day. Furosemide should be given in divided doses because of its short duration of action.

- If BP control is not achieved, review drug adherence; sodium restriction is warranted and $\mathrm{BP}$ control outside the office with either home or 24-hour BP monitoring should be assessed to exclude the white coat effect.

- If after this the BP remains at $>130 / 80 \mathrm{mmHg}$, there are two options: add low-dose spironlactone 25 - $50 \mathrm{mg} /$ day, provided renal function is normal and $\mathrm{K}^{+}$is carefully monitored, or introduce agents that block the sympathetic nervous system. A $\beta$-blocker followed by a long-acting a-blocker or a centrally acting sympatholytic-like moxonidine is a rational strategy.

- In recalcitrant patients consider minoxidil, but avoid long-term use in females and be aware of possible pericardial effusion in stages 4 and $5 \mathrm{CKD}$.

\section{Summary}

Control of hypertension is the most important factor in the primary prevention and progression of CKD. In patients with $\mathrm{CKD}$, the goal $\mathrm{BP}$ is $<130 / 80 \mathrm{mmHg}$ and first-line therapy is the administration of an RAS inhibitor. However, multiple agents are often required to achieve the BP target.

\section{Diabetic patients ${ }^{[2]}$}

- $\mathrm{DM}$ is the most common cause of CKD worldwide.

- Both type 1 and 2 DM are on the increase.

- The incidence of CVDs is increased in diabetic patients.

\section{Diagnosis of diabetic nephropathy}

- It normally develops after DM duration of $>10$ years.
The clinical stages of diabetic nephropathy are given in Table 1 .

\section{Preservation of renal function}

- Strict glycaemic control. $\mathrm{HbA}_{1 \mathrm{c}}<6.5 \%$.

- BP control. Aim for $<130 / 80 \mathrm{mmHg}$. Avoid systolic BP $<110 \mathrm{mmHg}$.

- Use ACE inhibitors or ARBs as first-line therapy.

- Add other classes of BP medications to achieve the target BP.

- Reduce proteinuria. Administer ACE inhibitors or ARBs for an antiproteinuric effect.

- Restrict salt intake (4 - 6 g/24 hours)

- Prevention of acute kidney injury. Avoid nephrotoxins (NSAIDs, aminoglycosides, $\mathrm{X}$-ray contrast media).

- Attention to CVD risk. Most patients with $\mathrm{DM}$ and CKD do not reach stage 5 CKD, as they die early owing to CVD.

- Lifestyle and nutrition. ${ }^{[4]}$ Aerobic exercise daily for approximately 30 minutes is recommended. Smoking should be discontinued. Weight should be reduced. Patients should be on a protein-restricted diet $(0.6-0.8 \mathrm{~g} / \mathrm{kg} /$ day predialysis; $1.2 \mathrm{~g} / \mathrm{kg} /$ day on dialysis).

\section{Table 1. Clinical stages of diabetic nephropathy ${ }^{[3]}$}

\begin{tabular}{lllll}
\hline Stage & GFR & UAE & $\begin{array}{l}\text { Blood } \\
\text { pressure }\end{array}$ & Years \\
\hline 1. Hyperfiltration & Super normal & $<30 \mathrm{mg} /$ day & Normal & $0-5$ \\
2. Microalbuminuria & High normal - normal & $30-300 \mathrm{mg} /$ day & Rising & $5-15$ \\
3. Overt proteinuria & Normal - decreasing & $>300 \mathrm{mg} /$ day & Elevated & $10-20$ \\
4. Progressive nephropathy & Decreasing & Increasing & Elevated & $15-25$ \\
5. ESKD & $<15 \mathrm{~mL} / \mathrm{min}$ & Massive & Elevated & $20-30$
\end{tabular}

ESKD = end-stage renal disease; GFR = glomerular filtration rate; $\mathrm{UAE}$ = urinary albumin excretion

Table 2. Modifications of antidiabetic drugs in patients with type 2 diabetes mellitus (adapted from the Kidney Disease Outcomes Quality Initiative (KDOQI) guidelines)

\begin{tabular}{|c|c|c|c|}
\hline Class & Drug & $\begin{array}{l}\text { Dosing recommendation stages } 3 \text { and } 4 \text { CKD or } \\
\text { kidney transplant }\end{array}$ & Dosing recommendation dialysis \\
\hline \multirow[t]{2}{*}{$\begin{array}{l}\text { First-generation } \\
\text { sulfonylureas }\end{array}$} & $\begin{array}{l}\text { Acetohexamide, tolazamide, } \\
\text { tolbutamide }\end{array}$ & Avoid & Avoid \\
\hline & Chlorpropamide & Avoid when GFR $<50 \mathrm{~mL} / \mathrm{min} / 1.73 \mathrm{~m}^{2}$ & Avoid \\
\hline \multirow{4}{*}{$\begin{array}{l}\text { Second-generation } \\
\text { sulfonylureas }\end{array}$} & Glipizide, gliclazide & Preferred sulfonylurea & Preferred sulfonylurea \\
\hline & & No dose adjustment & No dose adjustment \\
\hline & Glyburide & Avoid & Avoid \\
\hline & Glimepiride & Initiate at low dose, $1 \mathrm{mg} /$ day & Avoid \\
\hline a-glucosidase inhibitors & Acarbose & Not recommended if serum creatinine $>180 \mu \mathrm{mol} / \mathrm{L}$ & Avoid \\
\hline Biguanides & Metformin & See text & Avoid \\
\hline \multirow[t]{2}{*}{ Meglitinides } & Repaglinide & No dose adjustment & Avoid \\
\hline & Nateglinide & Initiate at low dose (60 mg before each meal) & Avoid \\
\hline Thiazolidinediones & Pioglitazone, rosiglitazone & No dose adjustment & No dose adjustment \\
\hline
\end{tabular}




\section{Pharmacological treatment of DM}

Patients with stages 3 - 5 CKD are at risk of hypoglycaemia because of:

- decreased renal clearance of insulin and sulfonylureas

- impaired renal gluconeogenesis.

\section{Type 1 DM}

Insulin needs may change with decreasing renal function, as CKD is associated with insulin resistance and there is decreased renal clearance of insulin with advancing CKD.

\section{Type 2 DM}

A number of different oral hypoglycaemic drugs are available (Table 2).

The benefits of intensive therapy are independent of the type of treatment administered.

\section{Metformin}

Metformin should be used with caution in patients with stages 4 and 5 CKD. Its use in CKD carries a small risk of severe lactic acidosis; the risk increases with decreasing glomerular filtration rate (GFR) and the dose should be adjusted.

The use of metformin should be reviewed when the patient reaches stage $3 \mathrm{CKD}$ and its use is contraindicated in stages 4 and $5 \mathrm{CKD}$.

\section{Sulfonylureas}

First-generation sulfonylureas should be avoided. Second-generation sulfonylureas may be used in patients who have learnt to avoid hypoglycaemic episodes, as long as their diabetes is controlled and nutritional status is satisfactory.

\section{Thiazolidinediones}

These may be used in patients without heart failure. Caution is advised in patients with ischaemic heart disease.

\section{Insulin}

When insulin therapy is used, care should be taken to avoid hypoglycaemic episodes, as the renal clearance of insulin declines with advancing renal impairment.

\section{Newer antidiabetic drugs}

- DPP-4 antagonists (vildagliptin, saxagliptin) can be used with dose adjustments. Avoid combination drugs that also contain metformin.

- GLP-1 receptor agonists (exenatide, liraglutide). These should not be used in moderate renal function impairment (creatinine clearance $<30 \mathrm{~mL} / \mathrm{min}$ )

\section{HIV and CKD}

\section{Global prevalence of HIV infection}

There are an estimated 35 million people infected with HIV, 68\% of whom are in sub-Saharan Africa (SSA). Southern Africa is the worst affected, with the national adult HIV prevalence exceeding $15 \%$ in eight southern African countries. ${ }^{[5]}$

\section{Table 3. Spectrum of renal disease in HIV}

- Electrolyte and acid-base disturbances

- Acute kidney injury

- $\mathrm{CKD}$

- Intrinsic renal disease unrelated to HIV itself (e.g. DM and hypertension)

- HIV-associated glomerulonephropathies: may present as acute-on-chronic or chronic renal failure; this group is primarily implicated in the burden of CKD

- Acute-on-chronic kidney disease

- Side-effects related to treatment of HIV (ART and drugs used to treat complications of HIV)

- Long-term metabolic side-effects of ART

Table 4. Spectrum of glomerular disease in HIV

\begin{tabular}{|c|c|}
\hline Glomerular pattern & Subtypes \\
\hline HIV-FGS or 'classic' HIVAN (HIV-associated nephropathy) & $\begin{array}{l}\text { Some have described a mixed variant of HIV-FGS in } \\
\text { combination with a proliferative glomerulonephritis }\end{array}$ \\
\hline HIV-ICD (this group of patients may have co-infection with hepatitis B or C) & $\begin{array}{l}\text { Mesangial proliferative } \\
\text { Membranoproliferative (type I and III) } \\
\text { Lupus-like } \\
\text { Exudative-proliferative } \\
\text { Crescentic } \\
\text { IgA } \\
\text { Membranous }\end{array}$ \\
\hline Various glomerulonephropathies (this is a heterogeneous group with different aetiologies) & $\begin{array}{l}\text { Minimal change } \\
\text { Immunotactoid } \\
\text { Amyloidosis }\end{array}$ \\
\hline HIV-TTP/HUS & TTP/HUS \\
\hline Comorbid disease & $\begin{array}{l}\text { Diabetic nephropathy } \\
\text { Hypertensive nephrosclerosis } \\
\text { Auto-immune disease (e.g. lupus nephritis) }\end{array}$ \\
\hline
\end{tabular}


Table 5. Dose adjustments for ART in CKD and ESKD ${ }^{[19]}$

\begin{tabular}{|c|c|c|c|}
\hline Agent & \multicolumn{2}{|c|}{ CKD (adjusted according to creatinine clearance, or by eGFR) } & Dialysis \\
\hline \multicolumn{4}{|l|}{ Nucleoside/ nucleotide analogues } \\
\hline Abacavir & \multicolumn{2}{|l|}{ No adjustment } & $\begin{array}{l}\text { No adjustment. HD: dosing } \\
\text { independent of dialysis sessions }\end{array}$ \\
\hline Azidothymidine/zidovudine (AZT) ${ }^{*}$ & \multicolumn{2}{|l|}{$\begin{array}{l}\mathrm{Cr} \mathrm{cl} \geq 15 \mathrm{~mL} / \mathrm{min}: \text { no adjustment } \\
\mathrm{Cr} \mathrm{cl}<15 \mathrm{~mL} / \mathrm{min}: 100 \mathrm{mg} \text { po q } 6-8 \mathrm{~h}\end{array}$} & $\begin{array}{l}100 \mathrm{mg} \text { po q } 6-8 \mathrm{~h}^{*} \\
\text { or } 300 \mathrm{mg} \text { po qd }\end{array}$ \\
\hline Didanosine (ddi) & $\begin{array}{l}\text { Weight }>60 \mathbf{~ k g} \\
\mathrm{Cr} \mathrm{cl} 30-59 \mathrm{~mL} / \mathrm{min}: 200 \mathrm{mg} \text { po qd } \\
\mathrm{Cr} \mathrm{cl} 10-29 \mathrm{~mL} / \mathrm{min}: 125 \mathrm{mg} \text { po qd } \\
\mathrm{Cr} \mathrm{cl}<10 \mathrm{~mL} / \mathrm{min}: 125 \mathrm{mg} \text { po qd }\end{array}$ & $\begin{array}{l}\text { Weight }<60 \mathbf{~ k g} \\
125 \mathrm{mg} \text { po qd } \\
100 \mathrm{mg} \text { po qd } \\
75 \mathrm{mg} \text { po qd }\end{array}$ & Dose for $\mathrm{Cr} \mathrm{cl}<10 \mathrm{~mL} / \mathrm{min}^{+}$ \\
\hline Emtricitabine $^{*}$ & \multicolumn{2}{|l|}{$\begin{array}{l}\mathrm{Cr} \mathrm{cl}>50 \mathrm{~mL} / \mathrm{min} \text { : no adjustment } \\
\mathrm{Cr} \mathrm{cl} 30-49 \mathrm{~mL} / \mathrm{min}: 200 \mathrm{mg} \text { po q } 48 \mathrm{~h} \\
\mathrm{Cr} \mathrm{cl} 15-29 \mathrm{~mL} / \mathrm{min}: 200 \mathrm{mg} \text { po q } 72 \mathrm{~h} \\
\mathrm{Cr} \mathrm{cl}<15 \mathrm{~mL} / \mathrm{min}: 200 \mathrm{mg} \text { po q } 96 \mathrm{~h}\end{array}$} & $\begin{array}{l}200 \mathrm{mg} \text { po } \mathrm{q} 96 \mathrm{~h}^{\dagger} \\
\text { PD: no data }\end{array}$ \\
\hline Lamivudine (3TC) ${ }^{*}$ & \multicolumn{2}{|c|}{$\begin{array}{l}\mathrm{Cr} \mathrm{cl}>50 \mathrm{~mL} / \mathrm{min} \text { : no adjustment } \\
\mathrm{Crcl} 30-49 \mathrm{~mL} / \mathrm{min}: 150 \mathrm{mg} \text { po qd } \\
\mathrm{Crcl} 15-29 \mathrm{~mL} / \mathrm{min}: 150 \mathrm{mg} \text { first dose, then } 100 \mathrm{mg} \text { po qd } \\
\mathrm{Crcl} 5-14 \mathrm{~mL} / \mathrm{min}: 150 \mathrm{mg} \text { first dose, then } 50 \mathrm{mg} \text { po qd } \\
\mathrm{Cr} \mathrm{cl}<5 \mathrm{~mL} / \mathrm{min}: 150 \mathrm{mg} \text { first dose, then } 25 \mathrm{mg} \text { po qd }\end{array}$} & $\begin{array}{l}150 \mathrm{mg} \text { first dose, } \\
\text { then } 25 \mathrm{mg} \text { po } \mathrm{qd}^{\dagger}\end{array}$ \\
\hline Stavudine $(\mathrm{d} 4 \mathrm{~T})$ & \multicolumn{2}{|l|}{$\begin{array}{l}\mathrm{Cr} \mathrm{cl}>50 \mathrm{~mL} / \mathrm{min}: \text { no adjustment } \\
\mathrm{Cr} \mathrm{cl} 26-50 \mathrm{~mL} / \mathrm{min}: 15-20 \mathrm{mg} \text { po bid } \\
\mathrm{Cr} \mathrm{cl} \leq 25 \mathrm{~mL} / \mathrm{min}: 15-20 \mathrm{mg} \text { po qd }\end{array}$} & $\begin{array}{l}20 \mathrm{mg} \text { po } \mathrm{qd}^{\dagger} \\
\text { PD: has been used safely }\end{array}$ \\
\hline Tenofovir & \multicolumn{2}{|l|}{$\begin{array}{l}\mathrm{Cr} \mathrm{cl}>50 \mathrm{~mL} / \mathrm{min}: \text { no adjustment } \\
\mathrm{Cr} \mathrm{cl} 30-49 \mathrm{~mL} / \mathrm{min}: 300 \mathrm{mg} \mathrm{q} 48 \mathrm{~h} \\
\mathrm{Crcl} 10-29 \mathrm{~mL} / \mathrm{min}: 300 \mathrm{mg} \mathrm{q} 72 \mathrm{~h}\end{array}$} & $300 \mathrm{mg}$ po every 7 days $^{\dagger}$ \\
\hline Zalcitabine & \multicolumn{2}{|l|}{$\begin{array}{l}\mathrm{Cr} \mathrm{cl} \geq 40 \mathrm{~mL} / \mathrm{min}: \text { no adjustment } \\
\mathrm{Cr} \mathrm{cl} 10-40 \mathrm{~mL} / \mathrm{min}: 0.75 \mathrm{mg} \mathrm{q} 12 \mathrm{~h} \\
\mathrm{Cr} \mathrm{cl}<10 \mathrm{~mL} / \mathrm{min}: 0.75 \mathrm{mg} \mathrm{q} 24 \mathrm{~h}\end{array}$} & $\begin{array}{l}\mathrm{HD} \text { : dose for } \mathrm{Cr} \mathrm{cl}<10 \mathrm{~mL} / \mathrm{min}^{\dagger} \\
\text { PD: no data }\end{array}$ \\
\hline $\begin{array}{l}\text { Non-nucleoside reverse } \\
\text { transcriptase inhibitors }\end{array}$ & \multicolumn{2}{|l|}{ No adjustment } & \\
\hline Protease inhibitors & \multicolumn{2}{|l|}{ No adjustment } & No adjustment \\
\hline \multicolumn{4}{|l|}{ Entry/fusion inhibitor } \\
\hline Enfuvirtide & \multicolumn{2}{|c|}{$\begin{array}{l}\mathrm{Cr} \mathrm{cl} \geq 35 \mathrm{~mL} / \mathrm{min}: \text { no adjustment } \\
\mathrm{Cr} \mathrm{cl}<35 \mathrm{~mL} / \mathrm{min}: \text { unknown, use with caution }\end{array}$} & Unknown, use with caution \\
\hline \multicolumn{4}{|l|}{ CCR5 receptor antagonist } \\
\hline Maraviroc & \multicolumn{2}{|c|}{$\begin{array}{l}\text { No dosage recommendations } \\
\text { Patients with } \mathrm{Cr} \mathrm{cl}<50 \mathrm{~mL} / \mathrm{min} \text { should only receive maraviroc and } \\
\text { CYP3A inhibitor if potential benefit outweighs the risk }\end{array}$} & No data \\
\hline \multicolumn{4}{|l|}{ Integrase inhibitor } \\
\hline Raltegravir & \multicolumn{2}{|l|}{ No adjustment } & No adjustment \\
\hline
\end{tabular}

\section{Spectrum of kidney disease with HIV infection}

There is a wide clinical spectrum of renal disease (Tables 3 and 4) in the course of HIV infection.

\section{Acute kidney injury in HIV}

The causes of acute kidney injury (AKI) in hospitalised HIVinfected patients may be community or hospital acquired, the latter being 5 - 10 times more common than the former, with a worse outcome in hospital-acquired AKI. ${ }^{[6]}$ The known causes of AKI are similar in HIV and non-HIV groups, the most common being acute tubular necrosis (ATN), secondary to sepsis, hypotension, dehydration and nephrotoxicity. AKI is potentially reversible with appropriate medical treatment and, if indicated, dialysis support. ${ }^{[6,7]}$ In studies of hospitalised patients with HIV infection, AKI occurred in up to $20 \%$ of cases, and age and ethnicity contributed to mortality. In another study, the short-term prognosis in this group of patients showed mortality of $18 \%$ at 2 months, with $80 \%$ of patients diagnosed with AIDS at the time of hospital admission. Since the advent of ART (antiretroviral treatment), a prospective study on AKI in ambulatory HIV-infected outpatients with access to ART concluded that more severe immunosuppression (CD4 $<200$ cells $/ \mathrm{mm}^{3}$ and/ or HIV RNA level $>10000$ copies $/ \mathrm{mL}$ ) is still the predominant risk factor for AKI. ${ }^{[8]}$ 
Table 6. Common drug-drug interactions with ART ${ }^{[19]}$

\begin{tabular}{|c|c|c|}
\hline Class of drug & Concomitant medication & Effect \\
\hline \multirow[t]{10}{*}{ PIs } & Anticoagulant: warfarin & Variable, check INR \\
\hline & Anticonvulsants: carbamazepine, phenobarbital, phenytoin & Variable, recommend therapeutic drug monitoring \\
\hline & Antifungals: ketoconazole, itraconazole, voriconazole & Levels of antifungals increased \\
\hline & $\begin{array}{l}\text { Calcium channel blockers: diltiazem, nifedipine, verapamil, } \\
\text { amlodipine, nicardipine, isradipine, felodipine, bepridil }\end{array}$ & $\begin{array}{l}\text { Levels of CCBs increased } \\
\text { Life-threatening arrhythmias with bepridil }\end{array}$ \\
\hline & $\begin{array}{l}\text { HMG-CoA reductase inhibitors (statins): lovastatin, } \\
\text { simvastatin, atorvastatin }\end{array}$ & $\begin{array}{l}\text { Levels of statins increased - risk of myopathy/ } \\
\text { rhabdomyolysis }\end{array}$ \\
\hline & & Preferred: pravastatin, rosuvastatin, fluvastatin \\
\hline & Immunosuppressive drugs: cyclosporine, tacrolimus, sirolimus & $\begin{array}{l}\text { Levels of immunosuppressive drugs increased, recommend } \\
\text { therapeutic drug monitoring }\end{array}$ \\
\hline & Opioids: methadone & $\begin{array}{l}\text { Levels of methadone may decrease; therefore, may have to } \\
\text { increase dose }\end{array}$ \\
\hline & $\mathrm{PDE}_{5}$ inhibitors: sildenafil, vardenafil, tadalafil & $\begin{array}{l}\text { Levels of } \mathrm{PDE}_{5} \text { inhibitors increased, decrease dosage and } \\
\text { increase dosing interval }\end{array}$ \\
\hline & $\begin{array}{l}\text { Tricyclic antidepressants: amitriptyline, imipramine, } \\
\text { desipramine, trazodone }\end{array}$ & Levels of tricyclic antidepressants increased \\
\hline NNRTIs & $\begin{array}{l}\text { Calcium channel blockers: warfarin, anti-arrhythmics, } \mathrm{PDE}_{5} \\
\text { inhibitors, cyclosporine }\end{array}$ & $\begin{array}{l}\text { Plasma concentrations, clinical effects, and toxicities of } \\
\text { concomitant medications should be closely monitored } \\
\text { NNRTIs have less of an effect than PIs }\end{array}$ \\
\hline \multirow[t]{4}{*}{ Delaviridine } & Statins ${ }^{*}$ & Levels of statins significantly increased \\
\hline & Anticonvulsants & $\begin{array}{l}\text { Carbamazepine, phenobarbital, phenytoin contraindicated } \\
\text { due to very low levels of delaviridine }\end{array}$ \\
\hline & Glucocorticoids & Levels of glucorticoids increased \\
\hline & Immunosuppressives & Levels of sirolimus and tacrolimus increased \\
\hline \multirow[t]{2}{*}{ Efavirenz } & Statins & Levels of atorvastatin and simvastatin decreased \\
\hline & Glucocorticoids & Levels of glucocorticoids decreased \\
\hline \multirow[t]{2}{*}{ Nevirapine } & Fluconazole & Fluconazole may double nevirapine levels \\
\hline & Glucocorticoids & Levels of glucocorticoids decreased \\
\hline $\begin{array}{l}\text { NRTIs } \\
\text { and fusion } \\
\text { inhibitors }\end{array}$ & $\begin{array}{l}\text { Little or no effect on hepatic cytochrome P450 } \\
\text { metabolism }\end{array}$ & Few drug-drug interactions \\
\hline
\end{tabular}

\section{HIV-associated CKD (HIV-CKD)}

Screening studies from Africa differ widely in their reported prevalence of kidney disease in HIV. In most studies the prevalence of kidney disease has been assessed on the presence of albuminuria and/or estimated GFR (eGFR) (based on creatinine clearance). Studies from Africa have shown a variable prevalence of renal disease in HIV, ranging from $6 \%$ to $45 \%$ (6\% in SA, $38 \%$ in Nigeria, $26 \%$ in Cote d'Ivoire, $28 \%$ in Tanzania, 25\% in Kenya, 20 - 48.5\% in Uganda, and 33.5\% in Zambia), depending on the populations studied and the criteria for diagnosis of kidney disease. Part of this wide variation may be ascribed to differences in study design, populations studied and definitions used for CKD. Recent literature recommends the CKD-EPI formula as the most reliable in calculating eGFR in this patient population. ${ }^{[9]}$ Very few studies detail the histological pattern of kidney disease on kidney biopsy and, fewer still, the response to treatment.

\section{HIV-associated nephropathy (HIVAN)}

Most African patients with HIVAN present late, with advanced kidney failure. This late detection of HIVAN could be because of a lack of screening for proteinuria and/ or renal dysfunction and the relative absence of overt symptoms and signs, such as peripheral oedema and hypertension. Patient outcomes with HIVAN have been correlated with the clinical stage of their disease, suggesting that survival improves with earlier detection. ${ }^{[10]}$ There is an increased relative risk of 2.5 - 3.0 for overall mortality with proteinuria after correcting for other risk factors. In one study, $77 \%$ of renal abnormalities developed with CD4 counts $>200$ cells $/ \mathrm{mm}^{3}$. ${ }^{[1]}$ This was also seen in a study from SA where the mean
CD4 count of those with biopsy-proven HIVAN was 232 cells $/ \mathrm{mm}^{3}$. $^{[12]}$ HIVAN has been revised by the World Health Organization (WHO) as stage 4 disease, thus emphasising the need for initiation of ART in this condition, irrespective of the CD4 count. The initial description of HIVAN in individuals of African descent has been attributed to the presence of APOL1 genetic variants. ${ }^{[13]}$

\section{Screening for CKD in HIV}

Statistics in the USA estimate the incidence of HIVAN as $3.5-12 \%$. $^{[1]}$ If this were to be extrapolated to SSA, where an estimated 22 million are infected with HIV, between 770000 and 2.64 million people would be predicted to have HIVAN. With the advent of wider access to ART, the epidemiological pattern of HIVAN that evolved in the USA over the last 14 years 


\section{Table 7. Other causes of CKD}

\begin{tabular}{|c|c|c|c|c|}
\hline \multirow[b]{2}{*}{ Disorder } & \multicolumn{2}{|c|}{ Age groups } & \multicolumn{2}{|c|}{ Ethnic groups } \\
\hline & $<45$ years & $>45$ years & Black & Other \\
\hline \multicolumn{5}{|l|}{ Congenital/ inherited } \\
\hline - $\mathrm{ADPKD}$ & & & + & ++ \\
\hline - RTA & & & & + \\
\hline \multicolumn{5}{|l|}{ Glomerular disease } \\
\hline - Primary & +++ & & ++ & + \\
\hline - Secondary & + & + & & + \\
\hline - PSGN & + & & + & \\
\hline - SLE & +++ & + & ++ & + \\
\hline - Malignancies (e.g. myeloma) & & + & + & + \\
\hline \multicolumn{5}{|l|}{ Viral (not HIV) } \\
\hline - Hepatitis B & ++ & & ++ & + \\
\hline - Hepatitis C & $+1-$ & & $+1-$ & $+/-$ \\
\hline Renovascular $^{*}$ & + & ++ & $+/-$ & ++ \\
\hline Obstructive uropathy & + & + & + & $++^{+}$ \\
\hline Chronic pyelonephritis & ++ & + & $+/-$ & ++ \\
\hline Renal calculi & ++ & + & $+1-$ & +++ \\
\hline Toxicity (medication) & +++ & + & + & $+++^{*}$ \\
\hline \multicolumn{5}{|c|}{$\begin{array}{l}\text { ADPKD = autosomal-dominant polycystic kidney disease; PSGN = post-streptococcal glomerular nephritis; } \\
\text { RTA = renal tubular acidosis; SLE }=\text { systemic lupus erythematosus; +l-,+, ++,+++= frequency of diagnosis. } \\
{ }^{*} \text { Renovascular disease in young blacks, e.g. Takayasu syndrome (rare), or in older other ethnic groups, i.e. atheromatous. } \\
\text { 'Prostatic diseases. } \\
\text { 'Toxicity of therapeutic medicines. }\end{array}$} \\
\hline
\end{tabular}

may predict what will happen in SSA. This presents a potentially unprecedented burden of CKD. The Infectious Diseases Society of America published guidelines for the management of CKD in HIV in 2005, with a revision in 2014, which included recommendations for screening, ${ }^{[9]}$ e.g. all individuals should be assessed for kidney disease at the time of diagnosis of HIV infection and annually thereafter, with a screening urinalysis for proteinuria and estimation of renal function. It is important when interpreting the significance of proteinuria that it is persistent, as false positives are common in patients who may have comorbid conditions such as infection. Failing to confirm persistence of proteinuria can significantly impact on the number of referrals in high-prevalence populations. Any patient with persistent proteinuria, persistent haematuria or a GFR $<60 \mathrm{~mL} / \mathrm{min} / 1.73 \mathrm{~m}^{2}$ should therefore be referred to an institution where a specialist can evaluate the patient. An important caveat is that if no referral system is available, clinicians should initiate ART as early as possible to prevent progression to end-stage kidney diseases (ESKD). Considering the resource limitations in SSA, with particular reference to renal replacement therapy (RRT), it is imperative that screening, early detection and treatment of HIV-CKD be a public health priority. A screening algorithm (Fig. 1) is proposed for this purpose, accommodating resource-limited settings.

\section{ESKD due to HIV-CKD}

Life expectancy in HIV-infected patients has increased by 10 - 20 years in developed countries with the use of ART; many of these patients are now dying from the complications of ESKD and other chronic diseases, rather than HIV infection. Currently, HIV-infected patients requiring either haemodialysis or peritoneal dialysis, who are stable on ART, are achieving survival rates comparable with those of dialysis patients without HIV infection. The choice of dialysis modality does not impact on survival. ${ }^{[16]}$

Transplantation has been performed with success in HIV-infected patients. Preliminary short-term data in liver, kidney, and heart transplant recipients suggest that patient survival rates are similar to those in highrisk HIV-uninfected transplant recipients and there has been no increase in the prevalence of opportunistic infections. In spite of high rates of acute graft rejection, survival appears to be similar to high-risk HIV uninfected recipients. ${ }^{[17]}$ In areas with high endemic rates of HIV infection, in view of the shortage of donor organs, it has been proposed that
HIV-infected cadaveric donor organs may be transplanted into HIV-infected recipients with ESKD. Four such transplants have been reported in Cape Town, with good graft and recipient survival, but the data are preliminary. A further $>20$ such transplants have been performed, with good results. ${ }^{[18]}$

\section{Drugs and HIV-CKD}

In addition to ART, patients are treated for opportunistic infections, malignancies, and comorbid chronic illnesses (DM/hypertension) and may be given immunosuppression for kidney transplantation. HIV-CKD is compounded by the nephrotoxic potential of long-term ART.

\section{Dosing of ART in CKD}

Many ARTs are partially or completely eliminated by the kidney and require dose adjustment in CKD; hence the necessity to measure renal function (Table 5). Certain drug classes, such as the protease inhibitors (PIs) and the non-nucleoside reverse transcriptase inhibitors (NNRTIs), are metabolised by the liver and do not require dose adjustment. Entry/fusion inhibitors, integrase inhibitors, and CCR5 receptor antagonists also do not require dose adjustment. ${ }^{[19]}$ Most of the NRTIs are excreted unchanged in the urine and require dose adjustment, with the exception of zidovudine and abacavir, which have substantial extrarenal biotransformation requiring less or no dose adjustment. Factors that influence dialysability of ART relate to the properties of the dialysis membrane and molecular weight, degree of protein binding, molecular charge and water solubility of the drug. If removal of a drug occurs during haemodialysis, it should be taken after dialysis. If the drug is removed in peritoneal dialysis effluent, the dose may have to supplemented. Dosing recommendations in both haemo- and peritoneal dialysis are limited by the lack of reliable data. Fixed drug combinations should not be used in patients with an eGFR $<30-50 \mathrm{~mL} / \mathrm{min}^{[19]}$

\section{Drug interactions}

The NNRTIs and PIs are metabolised and eliminated by the hepatic and intestinal cytochrome P450 enzyme system, in particular CYP3A4 and P-glycoprotein. Most interactions are a consequence of enzyme induction or inhibition and there are many drug-drug interactions (Table 6). Certain overthe-counter preparations can affect drug levels, such as St John's Wort (Hypericum perforatum), which induces enzyme induction, causing lower PI and NNRTI levels. Concomitant use is not recommended. ${ }^{[19]}$ 


\section{Assessment for kidney disease in all HIV}

Risk factors: black race, family history of $\mathrm{CKD}$, use of nephrotoxic agents (including traditional medicines), diabetes mellitus, hepatitis C, HIV viral load $>4000$ copies $/ \mathrm{mL}$,

CD4 count $<200$ cells $/ \mathrm{mL}$

\section{Urine dipstick test for leucocytes}

If leucocytes and/or nitrites are present: urine microscopy and culture

Urinary tract infection(UTI) symptoms: treat empirically, adjust treatment according to culture results if indicated

Sterile pyuria: exclude sexually transmitted infection (STI) (including syphilis) and/or tuberculosis

\section{Urine dipstick test for proteinuria}

If negative, test for microalbuminuria. If no proteinuria or microalbuminuria, repeat screen in 12 months for those at risk of development of CKD

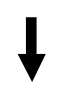

Proteinuria or microalbuminuria: exclude potential causes of proteinuria, e.g. fever, infection (UTI, STI, tuberculosis), pregnancy, uncontrolled diabetes, uncontrolled hypertension, cardiac failure Treat comorbid conditions: repeat urine dipstick in 1 month If nephrotic, nephritic or nephritic/nephrotic: refer for investigation and management Start antiretroviral treatment (ART)

At follow-up: persistent proteinuria/microalbuminuria and/or creatinine clearance $<60 \mathrm{~mL} / \mathrm{min} / 1.73 \mathrm{~m}^{2}$ - protein:creatine ratio or microalbumin:creatine ratio and investigate with kidney ultrasound scan, serological testing for hepatitis C, B, Plasmodium malariae (if appropriate, depending on infections endemic to the region), auto-immune screen Refer to a nephrologist, if a vailable

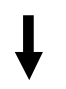

If unable to refer: ART - dose adjust according to eGFR

If still proteinuric after 3 months on ART: start antiproteinuric agents $\mathrm{K}^{+}<5.0 \mathrm{mmol} / \mathrm{L}$ : ACE inhibitor or $\mathrm{ARB}$ and check $\mathrm{K}^{+}$in one week $\mathrm{K}^{+}>5.0 \mathrm{mmol} / \mathrm{L}$ : potassium-binding resin or non-dihydropyridine calcium channel blocker (verapamil or diltiazem)

Gradual up-titration of dose, depending on tolerance and severity of proteinuria

Fig. 1. Management algorithm for screening HIV-infected patients for CKD (adapted from Fabian and Naicker ${ }^{[15]}$ ).

\section{Summary}

The extent of the HIV epidemic and its associated burden of CKD in SSA, coupled with the cost of RRT in a resource-limited setting, make it a challenging problem. The current stark reality in SA and many developing countries is that most people with ESKD and HIV die; some have limited access to dialysis. Most clinicians deal with advanced stages of CKD in HIV and prevention or early detection of renal disease in this population is neglected. Primary healthcare practitioners need a working system for screening, early detection and referral. Referral centres require resources for 
appropriate investigation and treatment of those with confirmed CKD.

\section{Other causes of CKD}

Other important but less frequently encountered causes of CKD are briefly presented, sub-divided into two divisions based on age and ethnicity (Table 7).

Additional causes of CKD are renal tuberculosis, sarcoidosis and a number of other inherited or acquired but rare conditions. If there is any suspicion of any of the abovementioned disorders, timeous referral to a nephrologist or specialist physician is important.

\section{References}

1. Seedat YK, Rayner BL; Southern African Hypertension Society. South African Hypertension Guideline 2011. S Afr Med J 2011:102(1 Pt 2):57-83.

2. National Kidney Foundation. KDOQAI Clinical Practice Guideline for Diabetes and CKD: 2012 Update. Clin J Kidney Dis 2012;60(5):850-886. [http://dx.doi.org/10.1053/j.ajkd.2012.07.005]

3. Parving H, Mauer M, Ritz E. Diabetic nephropathy. In: Brenner BM, ed. Brenner and Rector's the 3. Parving H, Mauer M, Ritz E. Diabetic nephropathy. In: Breng
Kidney. 7th ed. Philadelphia: WB Saunders, 2004:1777-1818

Kidney. 7th ed. Philadelphia: WB Saunders, 2004:1777-1818.
4. Phisitkul K, Hezagy K, Chauhirun T, et al. Continued smoking exacerbates but cessation ameliorates Phisitkul K, Hezagy K, Chauhirun T, et al. Continued smoking exacerbates but cessation ameliorates
progression of early type 2 diabetic nephropathy. Clin J Med Sci 2008;335(4):284-291. [http://dx.doi. progression of early type 2 diabetic nephropathy. Clin J Med Sci 2008;335(4):284-291. [http://dx.doi.

5. UNAIDS Report on the Global AIDS Epidemic 2013. www.unaids.org/en/resources/documents/2013 (accessed 25 February 2015).
6. Lameire N, Van Biesen W, Vanholder R. The changing epidemiology of acute renal failure. Nat Clin Pract Nephrol 2006;2(7):364-377. [http://dx.doi.org/10.1038/ncpneph0218]

7. Vachiat A, Musenge E, Wadee S, Naicker S. Renal failure in HIV-positive patients - a South African experience. Clin Kidney J 2013;0:1-6. [http://dx.doi.org/10.1093/ckj/stt128]

8. Franceschini NS, Napravnik WF, Finn LA, Szczech JJ, Eron JJ Jr. Immunosuppression, hepatitis C infection, and acute renal failure in HIV-infected patients. I Acquir Immune Defic Syndr 2006;42(3):368-372. [http://dx.doi.org/10.1097/01.qai.0000220165.79736.d3]

9. Lucas GM, Ross MJ, Stock PG, et al.; HIV Medicine Association of the Infectious Diseases Society of America. Clinical Practice Guideline for the Management of Chronic Kidney Disease in Patients Infected with HIV: 2014 Update. Clin Infect Dis 2014;59(9):e96-138. [http://dx.doi.org/10.1093/cid/ciu617]

10. Winston JA, Klotman PE. Are we missing an epidemic of HIV-associated nephropathy? J Am Soc Nephrol 1996;7:1-7.

11. Gardner LI, Holmberg SD, Williamson JM, et al. Development of proteinuria or elevated serum creatinine and mortality in HIV-infected women. J Acquir Immune Defic Syndr 2003;32(2):203-209. 12. Han TM, Naicker S, Ramdial PK, Assounga AG. A cross-sectional study of HIV-seropositive patients with varying degrees of proteinuria in South Africa. Kidney Int 2006;69(12):2243-2250. [http://dx.doi. org/10.1038/sj.ki.5000339]

13. Genovese G, Friedman DJ, Ross MD, et al. Association of trypanolytic ApoL1 variants with kidney disease in African Americans. Science 2010;329:841-845. [http://dx.doi.org/0.1681/ASN.2010070730] 14. Ross MJ, Klotman PE. Recent progress in HIV-associated nephropathy. J Am Soc Nephrol 2002;13(12): 2997-3004. [http://dx.doi.org/10.1097/01.ASN.0000040750.40907.99]

5. Fabian J, Naicker S. HIV and kidney disease in sub-Saharan Africa. Nat Rev Nephrol 2009;5(10):591598. [http://dx/doi/org/10.1038/nrneph.2009.141]

16. Soleymanian TS, Raman FN, Shannaq FN, et al. Survival and morbidity of HIV patients on hemodialysis and peritoneal dialysis: One center's experience and review of the literature. Int Urol Nephrol 2006;38(2):331-338. [http://dx.doi.org/10.1007/s11255-006-0080-8]

17. Stock PG, Roland ME, Carlson L, et al. Kidney and liver transplantation in human immunodeficiency virus-infected patients: A pilot safety and efficacy study. Transplantation 2003;76(2):370-375.

18. Muller E, Kahn D, Mendelsohn M. Renal transplantation between HIV positive donors and recipients. N Engl J Med 2010;362(24):2336-2337. [http://dx.doi.org/10.1056/NEJMc0900837]

19. Berns JS, Kasbekar JN. Highly active antiretrovial therapy and the kidney: An update on antiretroviral medications for nephrologists. Clin J Am Soc Nephrol 2006;1(1):117-129. 